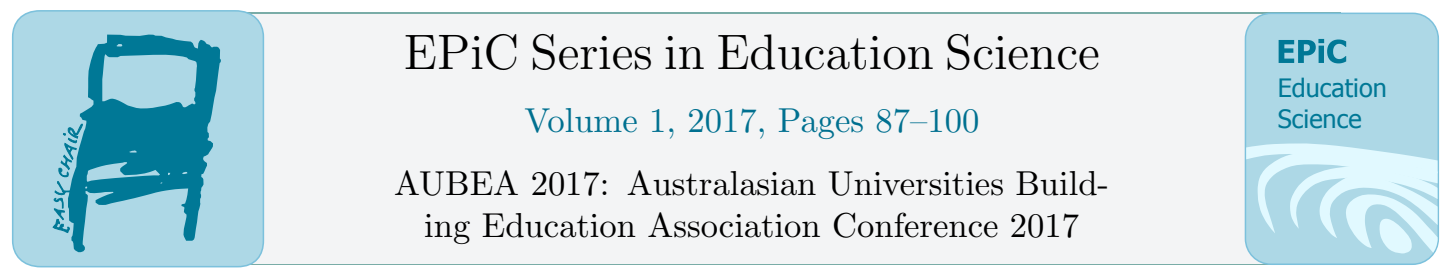

\title{
Improving Australian Commercial Property Market Forecasting by Mapping Structural Changes in Built Environment
}

Treshani Perera $^{1}$, Wejendra Reddy ${ }^{2}$

${ }^{1} \mathrm{PhD}$ Candidate, RMIT University, Melbourne, Australia

2Lecturer, RMIT University, Melbourne, Australia

treshani.perera@rmit.edu.au

\section{ABSTRACT}

Property market forecasting is an integral element of decisionmaking. It is critical that property analysts employ a wide - range of models and techniques for property forecasting. These models have one overriding aim of predicting reasonable estimates of key dependent variables (demand, supply, rent, yield, vacancy and net absorption) based on the independent variables of core economic activities. However, a broad-fronted social, economic, technical, political and ecological evolution can throw up sudden, unexpected shocks that result in a possibility of sceptical to unknown risk factors. These structural changes decrease, even eliminate predictability of property market performance. Hence, forecasting beyond econometrics is raised as the research problem in this study. This study follows a qualitative research approach, conducting semi-structured interviews with open-ended questions. The primary data were collected from 22 property stakeholders within Australia. Structural changes framework in the built environment is developed and categorised under PESTEL (Political, Economic, Social, Technological, Environmental, and Legal) factors. This framework was developed theoretically and subjected to 
empirical validation and improvement. Property conversions, integrated property functions in a single location, 'Give and Take' effect in property markets, NABERS compliance could be seen as emerging structural changes in the Australian commercial property markets. The understanding of the impact on the property market will provide a subjective overlay to improve the econometric forecasts.

Keywords: Built Environment, Commercial Property Market, Forecasting, Structural Changes.

\section{INTRODUCTION}

Real estate assets are characterised by lumpiness and illiquidity involving high unit cost that make decisions irreversible. In Australia, it is significant that direct commercial property investment transaction volumes is amount to approximately $8 \%$ of GDP (JLL, 2016). As real estate forms a major part of the mixed asset portfolio, it is critical that analysts and institutions employ a wide - range of techniques for forecasting the performance of real estate assets. Murray, Abelson, and Joyeux (2000) revealed the popularity of single and simultaneous equation regression models over univariate methods. These property market models have one overriding aim of predicting reasonable estimates of key dependent variables (demand, supply, rent, yield, vacancy and net absorption rate) based on current information.

All the stakeholders in the property market have a strong interest in forecasting. As their profitability and success depends on the reasonable estimates of key performance variables (Ball, Lizieri, and MacGregor, 1998; Brooks and Tsolacos, 2010). Accurate predictions can be conducted in a situation when ample quantitative data are available with a few uncertainties. For this type of problem, statistical methods can be employed for standard risk analysis (Aven, 2015).

However, a broad-fronted social, technical and ecological evolution can throw up sudden, unexpected shocks that result in a possibility of regression from Known back to unknown (Bardhan and 
Edelstein, 2010). However, the independent variables of core economic activity, and the possible disruption from structural changes and Black Swan events can make the econometric results sceptical to unknown risk factors. These extreme downside risk events have been often considered as statistical outliers in real estate modelling. Hence, the success of modern financial risk management in many instances are associated with understanding and managing extreme risk events (Higgins, 2014).

Therefore, modelling of the long-run trends and short-run fluctuations in the property market has become a great challenge. In addition to the reliance on underlying macroeconomic indicators, short term Black Swan events and long term structural changes and transformational forces are another two drivers that may impact upon real estate forecasting (Higgins, 2014). This research objective is to identify the structural changes in the built environment and map their potential impact on commercial property market performance. To do this, the research involved qualitative data collection from semi-structured interviews with 22 property professionals.

The understanding of the impact of structural changes in the Australian commercial property market will form a basis to give recommendations to adjust forecasts accordingly. The structure of this paper begins with a review of literature on structural changes to map the structural threats in the real estate environment. The next section presents the research methodology followed by qualitative data analysis. The last section provides the concluding remarks

\section{STRUCTURAL CHANGES}

Structural changes take place in response to the changes in core drivers of the economy, which is primarily concerned about the distribution of output across sectors, industries, states or regions (Productivity Commission, 2013). According to Prescott (2006), there must be a change in one or more of the four key variables: endowment, technology, preferences and institutions. Endowment refers to the factors of production available to the production process at a point in time. Technology includes the knowledge 
embodied in the hardware as well as intangible factors such as management practices and know-how. The preferences, refer to the consumer's utility level for different goods and services, in different quantities and combinations. The fourth one 'institutions' refers to the set of laws, rules and regulations, governance frameworks and policies. These sources of structural changes positioned a new equilibrium on the production frontier.

In the real estate sector of the economy, structural changes in property market impact the future use and demand for real estate globally over years and decades. Since 1993, the University of Reading has undertaken an annual survey of corporate real estate practice. A longitudinal analysis over a long period enabled a detail analysis of the major trends in the corporate real estate. Gibson and Luck (2006) identified four major trends in corporate real estate: new working practices, outsourcing, technological infrastructure and corporate real estate management and strategy. According to Bardhan and Edelstein (2010), major structural changes in real estate are driven by a number of economic and non-economic factors: socio-cultural, technological developments, economic/regulatory changes, changes in financial systems.

Additionally, demographic factors such as growth of the population, household formation and ageing demographics of the population (McMahan, 2006; Rowland, 2010) and environmental factors such as land degradation, responses to the climate change and preferences for green concept towards sustainability were discussed under structural changes in real estate (Rowland, 2010). Haynes and Nunnington (2010) introduced six sector approach to categorise each driving forces into demography, society, economy, governance, technology and environment through environmental scanning. The historical background of real estate frontier highlights how several non-economic sources of uncertainty have interacted with real estate market and driven into major changes, for examples: development of property rights, massive rural-urban migration, changing feudal structure, industrial capitalism, evolution of the structure of family, creation of specialised real estate, technological advances such as the invention of new material, advanced engineering techniques and the development in 
the field of finance leads to the emergence of modern finance (Bardhan and Edelstein, 2010).

Megatrends tap into sustained evolutionary trends that impact at a global level across PESTEL factors. Although these factors influence real estate performance, the extent and timing of changes are generally hard to predict. Yet, real estate investors need to consider the industry drivers of a city's economy in order to anticipate the scale and nature of demand for real estate, and gain benefits of structural changes (Rowland, 2010; TIAA Henderson Real Estate, 2014). Adhering to the understanding of the available literature, PESTEL approach is used to sort these changes in the real estate environment as summarised below in Figure 1.

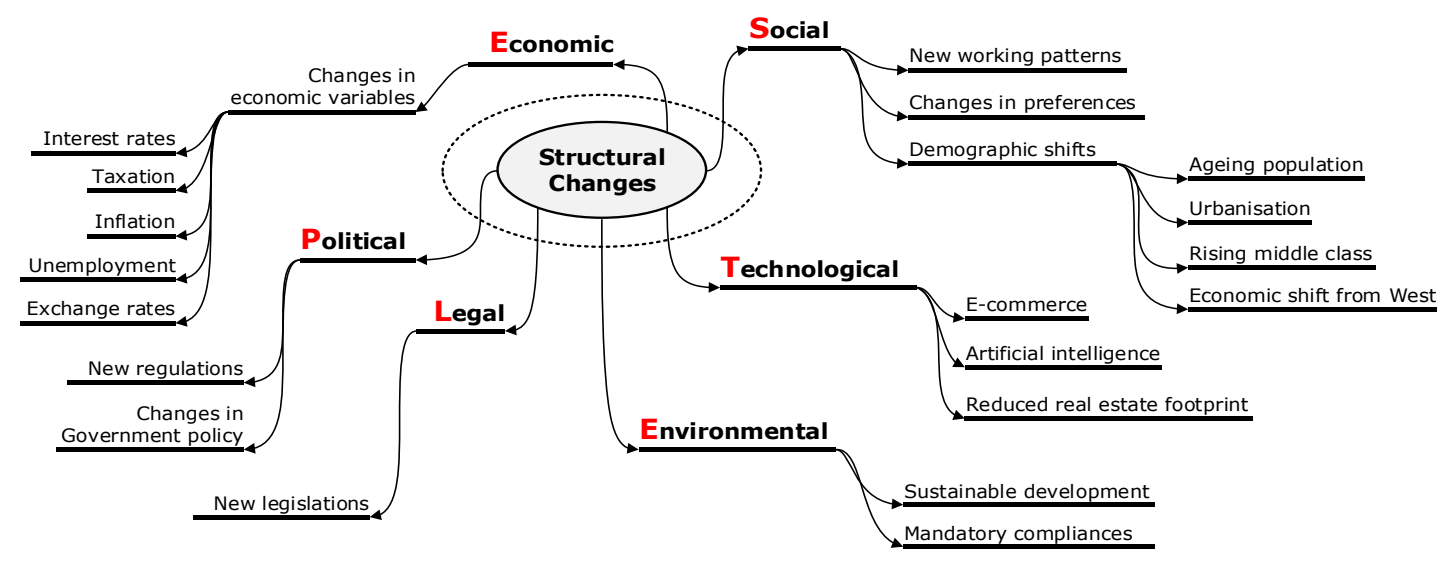

Figure 1 Conceptual Map of Structural Changes in the Built Environment

Given the emphasis to the specific structural changes in Figure 1, the most significant macroeconomic medium that affects real estate is through the credit market via interest rate. The impact is significant due to higher gearing levels which significantly add to the cost of capital. In terms of technological forces, globalisation is a driver of the real estate economy with increasing economic and financial integration whilst brings an elevated risk of contagion (Bardhan and Edelstein, 2010). Further, Sustainable development as an environmental structural change has given prominence under four coherent push factors: financial motivation (Corporate Social Responsibility), government interference (tax credit schemes), 
standardisation and harmonisation indicators (green building rating systems) and empirical evidence (Lützkendorf and Lorenz, 2005).

\section{RESEARCH METHODOLOGY}

In the real estate context, Clapp and Myers as cited in Leishman (2003) stated that the form of deductive reasoning has dominated the real estate economics research since the 1960s which focus on the construction of sophisticated models using quantitative techniques. The change in the research paradigm has been forwarded with the idea of behavioural real estate market research in order to capture the qualitative information. Ball et al. (1998) described the research belonging to this agenda as 'behavioural institutionalism'.

Hence, this research falls into critical realism philosophical orientation focussing on what we see and experience, in terms of the underlying structures of reality in the Australian commercial property market. The methodology employs inductive reasoning that involves collecting qualitative data from semi-structured interviews among 22 property professionals: property analysts (9), economists (4), fund managers (7) and lenders (2). Property analysts and economists provide real estate research and advice to fund managers for their direct property investment decision making while lenders provide the financial assistance.

This qualitative research inquiry involves four key interview themes: (i) current forecasting practice, (ii) forecast errors, (iii) factors beyond econometrics and (iv) proactive strategies to improve forecasts. This paper presents the analysis of the factors beyond econometrics and their impact on commercial property market. The qualitative data generated from interview transcripts were analysed thematically. Major themes and sub themes were formulated in accordance to requirements of the research objectives using QSR NVIVO 11 software. 


\section{ANALYSIS AND DISCUSSION}

Through the literature review, a number of reasons were identified to explain potential changes in the property sector and classified under PESTEL framework. This section synthesised the primary data to explore the structural changes more specifically in Australia to validate the conceptual map illustrated in Figure 1. Further, the practical impact of improved forecasting for the property sector is also highlighted.

\section{Political and Legal Structural Changes}

Interview participants when questioned about asserted that political shifts and policy changes are unpredictable and there is a quite high risk involved in investment decision making due to political fluctuations. Most experts interviewed indicated that it was getting harder for econometrics to stick in a dummy variable to anticipate structural changes. Thus, investors are being driven to invest accordingly with the shocks from a macro level.

Further, inherent characteristics of the direct property market have been a contributing factor in cascading the impact of the structural changes. A property analyst emphasised the incapability of the inelastic supply to match with the rising demand due to political and legal pressures:

"Things like changes in the planning regime, changes in rules about cross-border capital flows. If the Chinese decide to clamp down on flows of capital out of China ........those shocks can be quite important for property because property tends to be a very inelastic and fixed asset, it doesn't react very well to changes in demand. Inherently there's always a risk in property which you can't do very much about" (Property Analyst).

\section{Economic Structural Changes}

Most of the participants raised mining boom as a key structural change in the Australian economy. Apart from that, interview respondents have identified following economic structural changes. 
- The rise in the dollar leads to the destruction of the competitiveness of the dollar exposed industries.

- Office and industrial are almost cyclical assets over the retail industry. Therefore, fund managers tend to focus on retail over the other commercial property asset classes.

- Employment as a key variable in the macro-economics is subjected to high mobility with new industries come along and change the movement of the workforce.

- A higher degree of outsourcing and subcontracting of professional services to smaller firms is apparent with the strong growth of smaller tenants who would lease less than $1000 \mathrm{~m}^{2}$ of space. Whilst larger firms are adopting more efficient work space configurations.

- The change in the function of the property product through conversions is becoming a trend.

Further elaborating the property conversions, there is an increased tendency of office properties in the inner ring suburbs of Australian market is converted to residential apartments, student accommodations and hotels. Further, industrial buildings in the middle ring are likely to convert to residential. The following quotations from the respondents provide the reasons for these conversions for property products.

"Office markets such as North Sydney or down in Melbourne St. Kilda Road which were traditionally the second largest office markets in the CBD. Their importance in office marketers has diminished over the last 5 years, I've seen a number of properties being converted to residential, their stocks fallen for by some of 20\%" (Lender-Property market).

"As a response to a lot of vacancy in a $B$ grade office building next to our building .........they decided to let's just change the building and it's all student accommodation they started putting in kitchens and bathrooms everywhere. Then the person across the road, just went - that's a great idea, let's do the same" (Property Fund Executive). 
"Industrial areas in the middle ring suburbs surrounded by residential: Footscray, Sun-shine coast going to be residential soon" (Investment Managed Fund Executive).

These structural changes reflected in the macro-economic indicators such as exchange rate, national income, unemployment rate. However, the movement in 10 years bond rate has not been significantly identified in the interview survey. Yet, the participants emphasised the fact that the Australian economy is in a structurally low interest rate environment.

\section{Social Structural Changes}

All the participants affirmed the direct correlation of the population growth to the retail demand. Economists' forecast on population is factored in retail spending and subsequently the demand side net absorption modelling. Younger demographics and their wide internet absorption has become a push factor for the retail market improvement.

Infrastructure development is another key contributing factor to retail and industrial demand. Population growth is driven by infrastructure growth and vice versa. For instance, declining travel costs due to infrastructure improvement means suburbs in outer ring become more valuable (e.g. Bendigo). The similar cyclical relationship could be seen in between industrial demand and infrastructure development. This is justified by the following response of an interviewee.

"Industrial property is all about logistics and labour, goods and infrastructure. The most significant feature in property is infrastructure. Infrastructure is investments .........That is a materially significant feature, more than the other emerging features that haven't changed us anyway. It has changed where we invest in the industrial" (Property Analyst).

As another social shift, it is apparent that the integrated property facilities are delivered in buildings in addition to the core function of the building. Today's shopping centres do not merely serve the core function, but also integrate more non-retail facilities such as 
restaurants, entertainment areas. It is more like a social club, allowing people to socialise.

The same theme has been applied in the office environment, with the key purpose of differentiating the product. For example, respondents highlighted the need for employers nowadays to provide washrooms, lockers for employees riding to work on bicycles and likewise other supportive facilities within the office complex to cater for employee wellbeing. That helps attracting the tenants. However, this strategy is getting replicated among the rivals.

\section{Technological Structural Changes}

All three key sectors of the commercial property market were impacted by the factors illustrated in the conceptual map: ecommerce, reduced real estate footprint and artificial intelligence. These factors drive the performance of retail, office and industrial markets respectively. The respondents have agreed upon the transformational forces and further discussed about the status of real estate impact.

The online retail sector was profoundly deemed to being a substitution to the physical market. However, online retailing has not really made that much redundant in the physical asset. Penetration of eCommerce in Australia has been slower than other global markets. As per the Citi Research (2016), despite its strong growth in recent years, eCommerce sales were only about $4.5 \%$ of total retail sales. Whereas according to National Australia Bank (2016) analysis the impact of online retailing is $7.1 \%$ of bricks and mortar sales which means $6.6 \%$ of total retail sales. Further, the Amazon effect is highlighted by the respondents and its potential impact on electronic retailers. However, respondents highlighted that further improvement in delivery and transportation structure removes a significant impediment which will be then led to a material impact on retail real estate. In terms of forecasting the retail rental growth, it must be carefully factored retail sales component being modelled to factor the online linkage. 
Digital disruption has caused the office market to reduce the average workspace ratio through cloud offices, activity based working, casualisation, floating workstations/hot desking, open plan which allows greater workplace flexibility. This has not been a total industry disruption, but it will only marginalise relatively menial tasks in an office environment. Contrary to the theoretical advantages, participants explained the reality vs. expectation, elaborating that digital disruption has not yet been significant. It is more like 'Give and Take' effect on the office environment as justified by the following quotation.

"Companies use their space more efficiently like a lot of companies have hot-desking now .........I reckon while some sounds good and they're getting down the space requirements but in return they have a lot more break out areas, video conferencing rooms, all that sort of stuff. It's give and take. I don't think there's a huge impact there. I think they'll always be demand for offices" (Investment Managed Fund Executive).

Irrespective of the expectation of scattered office demand across the region with the technological advancement, office tenants are clustered in the CBDs resulted in high rental growth. Though big companies adhere to more efficient work space configurations, but more flexible new born operators/ start-ups have been a big driver of office space demand.

In addition to the use of artificial intelligence in the industrial market, participants revealed a similar 'Give and Take' effect from retail market (give) to industrial market (take) by offsetting the effects of online retail. The industrial market is benefitted by more demand for logistic facilities.

\section{Environmental Structural Changes}

NABERS rating has influence on the way commercial buildings are managed in Australia. It has strongly influenced investment decisions for existing and new buildings. The leasing structure of the Australian properties was affected by the mandatory compliance to the NABERS rating. The office sector is also beginning to adopt the green agenda as a marketing tool to let 
properties. The Property Council of Australia (PCA) includes NABERS Energy targets in its 'Guide to Office Building Quality' matrix. Depending on the requirement, property price is subjected to a premium or a discount. Hence, sustainable development is giving rise to the next industrial revolution.

\section{CONCLUDING REMARKS}

Structural changes decrease, even eliminate predictability of the property market. Hence, the research intended to improve property forecasting by identifying medium to long-term structural changes in real estate environment. The conceptual map developed in this research is grounded in the existing body of knowledge in the area of property and interview findings with 22 property experts. These structural changes are categorised under PESTEL factors and forwarded to the empirical validation and identifying the current reality in the market.

As key findings, the change in the function of the property product through conversions, the integrated property facilities in addition to the core function of the building, 'Give and Take' effect in office and industrial markets, NABERS compliance could be emerging structural changes in the Australian commercial property markets. These structural changes must be factored into forecasts without simply relying on the static past. This will form a platform for reliable decision making based on the forecasts. The understanding and mapping of the interactions among the structural changes identified in this research are important for property industry attempting to integrate the information into real estate forecasting. Although, this study is limited to the Australian commercial property market, it can be extended into other real estate sectors.

\section{REFERENCES}

Aven, T. (2015). 'Implications of black swans to the foundations and practice of risk assessment and management'. Reliability Engineering \& System Safety, Vol. 134, pp. 83-91. 
Ball, M., Lizieri, C., \& MacGregor, B. D. (1998). The Economics of Commercial Property Markets, Routledge, London.

Bardhan, A., \& Edelstein, R. H. (2010). Real estate through the ages: The known, the unknown, and the unknowable. In $X$. D. Francis, A. D. Neil, \& J. H. Richard (Eds.), The Known, the Unknown, and the Unknowable in Financial Risk Management: Measurement and Theory Advancing Practice, Princeton, Princeton University Press, pp. 145-163.

Brooks, C., \& Tsolacos, S. (2010). Real Estate Modelling and Forecasting (3 edn ed.), Cambridge University Press, Cambridge, UK.

Citi Research. (2016). What's in store? Issue 79: Is Amazon coming to Australia: Citi Research.

Gibson, V., \& Luck, R. (2006). 'Longitudinal analysis of corporate real estate practice: Changes in CRE strategy policies, functions and activities'. Facilities, Vol. 24 (3/4), pp. 74-89.

Haynes, B., \& Nunnington, N. (2010). Corporate Real Estate Asset Management-Strategy and Implementation, Elsevier Ltd., Oxford.

Higgins, D. (2014). Redefining commercial property market performance: Returns, risk and ruin. Paper presented at the 6th Annual Conference of Global Chinese Real Estate Congress.

JLL. (2016). Global real estate transparency index: JLL.

Leishman, C. (2003). Real estate market research and analysis, Palgrave Macmillan, Basingstoke.

Lützkendorf, T., \& Lorenz, D. (2005). 'Sustainable property investment: valuing sustainable buildings through property performance assessment'. Building Research \& Information, Vol. 33 (3), pp. 212-234.

McMahan, J. (2006). The Handbook of Commercial Real Estate Investing, McGraw-Hill, New York.

Murray, J., Abelson, P., \& Joyeux, R. (2000). 'Forecasting office rent in Sydney'. Economic Forecasting, Vol., pp. Allen \& Unwin, Sydney. 
National Australia Bank. (2016). NAB online retail index. http://business.nab.com.au/wpcontent/uploads/2017/02/norsi-december-2016.pdf viewed: 01 May 2017

Prescott, E. C. (2006). 'Nobel lecture: The transformation of macroeconomic policy and research'. Journal of Political Economy, Vol. 114 (2), pp. 203-235.

Productivity Commission. (2013). Looking back on structural change in Australia: 2002-2012.

http://www.pc.gov.au/about/governance/annualreports/2011-12/supplement/annual-report-2011-12supplement.pdf viewed: 08 March 2016

Rowland, P. (2010). Australian property investments and their financing, Lawbook Co, Sydney.

TIAA Henderson Real Estate. (2014). The 'Famous Five': The five demographic megatrends that real estate cannot ignore. https://www.threalestate.com/ /media/files/tomorrowsworld 2014-10-07-thefamousfive.pdf viewed: 20 January 2016 